\title{
Universiteit
}

Leiden

The Netherlands

\section{The political economy of land and water grabs}

Zetland, D.J.; Moeller-Gulland, J.; Allan, J.A.; Warner, J.; Sojamo, S.; Keulertz, M.

\section{Citation}

Zetland, D. J., \& Moeller-Gulland, J. (2012). The political economy of land and water grabs. In J. A. Allan, J. Warner, S. Sojamo, \& M. Keulertz (Eds.), The Handbook of Land and Water Grabs in Africa: Foreign Direct Investment and Food and Water Security (pp. 257-272). Oxford: Routledge. Retrieved from https://hdl.handle.net/1887/139055

Version: $\quad$ Not Applicable (or Unknown)

License: $\quad$ Leiden University Non-exclusive license

Downloaded from: https://hdl.handle.net/1887/139055

Note: To cite this publication please use the final published version (if applicable). 


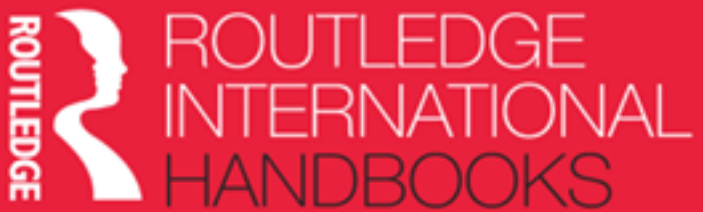

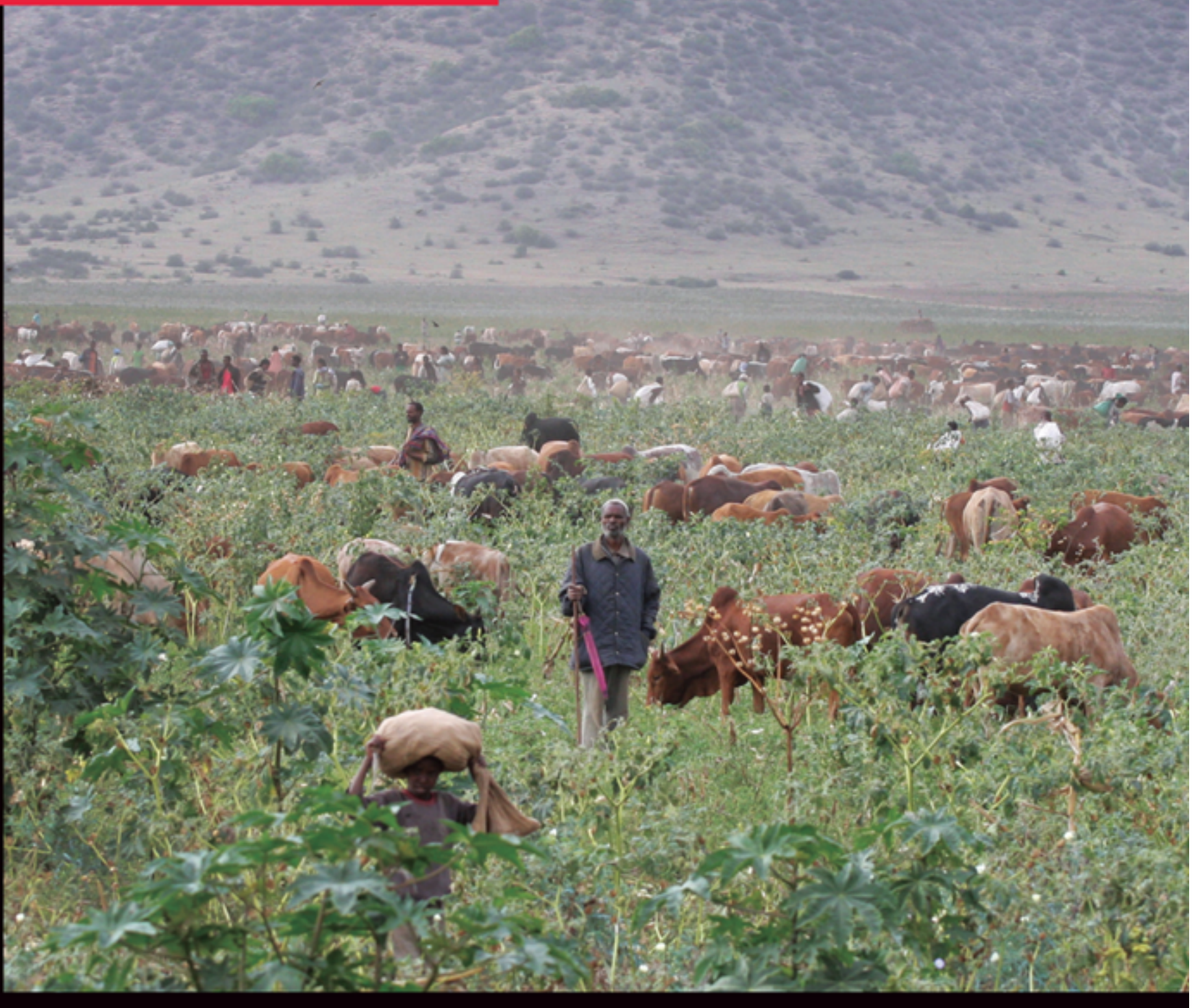

Handbook of Land and

Water Grabs in Africa

Foreign direct investment and food and water security

Edited by Tony Allan, Martin Keulertz, Suvi Sojamo and Jeroen Warner 


\section{Handbook of Land and Water Grabs in Africa}

Foreign direct investment and food and water security

Editors: Tony Allan, Martin Keulertz, Suvi Sojamo and Jeroen Warner 
First edition published 2013

by Routledge

2 Park Square, Milton Park, Abingdon, OX14 4RN, United Kingdom

Simultaneously published in the USA and Canada

by Routledge

711 Third Avenue, New York, NY 10017

Routledge is an imprint of the Taylor \& Francis Group, an informa business

○ 2013 Routledge

The right of the editors to be identified as the authors of the editorial material, and of the authors for their individual chapters, has been asserted in accordance with sections 77 and 78 of the Copyright, Designs and Patents Act 1988.

All rights reserved. No part of this book may be reprinted or reproduced or utilised in any form or by any electronic, mechanical, or other means, now known or hereafter invented, including photocopying and recording, or in any information storage or retrieval system, without permission in writing from the publishers.

Trademark notice: Product or corporate names may be trademarks or registered trademarks, and are used only for identification and explanation without intent to infringe.

Library of Congress Cataloging in Publication Data

Handbook of land and water grabs in Africa : foreign direct investment and food and water security / editors, Tony Allan ... [et al.]. - 1st ed.

p. $\mathrm{cm}$.

Includes bibliographical references and index.

1. Investments, Foreign-Africa. 2. Land tenure-Africa. 3. Land use-Africa. 4. Natural resources-Africa. 5. Food security-Africa. 6. Water security-Africa. I. Allan, J. A. John Anthony)

HG5822.H36 2012

$332.673096-\mathrm{dc} 23$

2012022401

ISBN: 978-1-85743-669-3 (hbk)

ISBN: 978-0-203-11094-2 (ebk)

Typeset in Bembo

by Taylor \& Francis Books

Europa Commissioning Editor: Cathy Hartley 


\section{Contents}

List of illustrations

ix

Acknowledgements

xii

The editors and contributors

xiv

Abbreviations

xxiii

Introduction: Can improving returns to food-water in Africa meet African food needs and the needs of other consumers?

J. A. (Tony) Allan

\section{PART I}

The history of land grabs and the contradictions of development

1.1 Enclosure revisited: putting the global land rush in historical perspective Liz Alden Wily

1.2 Land alienation under colonial and white settler governments in southern Africa: historical land 'grabbing'

Deborah Potts

1.3 Sudan and its agricultural revival: a regional breadbasket at last or another mirage in the desert?

Harry Verhoeven

1.4 The contradictions of development: primitive accumulation and geopolitics in the two Sudans

Clemens Hoffmann

1.5 The experience of land grabbing in Liberia

Niels Hahn 
Contents

PART II

Investors' profiles and current investment trends

2.1 Chinese engagement in African agriculture: fiction and fact Deborah Bräutigam

2.2 The global food crisis and the Gulf's quest for Africa's agricultural potential Eckart Woertz

2.3 A global enclosure: the geo-logics of Indian agro-investments in Africa Pádraig Carmody

2.4 Private investment in agriculture Mark Campanale

2.5 Domestic land acquisition in West Africa: the rush for farmland by urban 'businessmen' Thea Hilhorst and Joost Nelen

2.6 'Land grabs' and alternative modalities for agricultural investments in emerging markets Phil Riddell

2.7 Change in trend and new types of large-scale investments in Ethiopia Philipp Baumgartner

2.8 Tapping into Al-Andaluz resources: opportunities and challenges for investment in Morocco Nora Van Cauwenbergh and Samira Idllalene

2.9 A blue revolution for Zambia? Large-scale irrigation projects and land and water 'grabs'

Jessica M. Chu

\section{PART III}

\section{The political economy of land and water grabs}

3.1 Claiming (back) the land: the geopolitics of Egyptian and South African land and water grabs

Jeroen Warner, Antoinette Sebastian and Vanessa Empinotti

3.2 Land and water grabs and the green economy

\section{Martin Keulertz}


3.3 The political economy of land and water grabs

David Zetland and Jennifer Möller-Gulland

3.4 Will peak oil cause a rush for land in Africa?

Fabian Kesicki and Julia Tomei

3.5 How to govern the global rush for land and water?

Julia Ismar

3.6 Keep calm and carry on: what we can learn from the three food price crises of the 1940s, 1970s and 2007-2008

Johann Custodis

3.7 Constructing a new water future? An analysis of Ethiopia's current hydropower development

Nathanial Matthews, Alan Nicol and Wondwosen Michago Seide

3.8 Inverse globalisation? The global agricultural trade system and Asian investments in African land and water resources

Martin Keulertz and Suvi Sojamo

\section{PART IV}

Environment

4.1 Green and blue water dimensions of foreign direct investment in biofuel and food production in West Africa: the case of Ghana and Mali

Fred Kizito, Timothy O. Williams, Matthew McCartney and Teklu Erkossa

4.2 Green and blue water in Africa: how foreign direct investment can support sustainable intensification

Holger Hoff, Dieter Gerten and Katharina Waha

4.3 Groundwater in Africa: is there sufficient water to support the intensification of agriculture from 'land grabs'?

Alan M. MacDonald, Richard G. Taylor and Helen C. Bonsor

4.4 The water resource implications for and of FDI projects in Africa: a biophysical analysis of opportunity and risk

Mark Mulligan

4.5 Analyse to optimise: sustainable intensification of agricultural production through investment in integrated land and water management in Africa Michael Gilmont and Marta Antonelli 
Contents

PART V

Livelihoods

5.1 Expectations and implications of the rush for land: understanding the opportunities and risks at stake in Africa

Ward Anseeuw, Lorenzo Cotula and Mike Taylor

5.2 China-Africa agricultural co-operation, African land tenure reform and sustainable farmland investments

Yongjun Zhao and Xiuli Xu

5.3 Competing narratives of land reform in South Sudan

David K. Deng

5.4 Struggles and resistance against land dispossession in Africa: an overview Elisa Greco

Index 


\title{
3.3
}

\section{The political economy of land and water grabs}

\author{
David Zetland and Jennifer Möller-Gulland ${ }^{1}$
}

\section{Introduction: land grabs are not so new}

Foreigners have invested in international land assets for many centuries, but the recent increase in 'land grabs' appears to be a 'bad' form of foreign direct investment (FDI). Unlike FDI that shares the gains from trade with locals over a longer time horizon, land grabs maximise unsustainable returns in the short run with inadequate compensation to local communities. For the purposes of this chapter, we will therefore divide deals (or investments) into two types: 'land grabs' that transfer land and water rights from existing users without fair compensation and FDI that does provide fair compensation. ${ }^{2}$

Consider a deal to use land worth US $\$ 100$ under traditional cultivation. A foreign investor may offer $\$ 200$ to cultivate that land with improved technology that increases output and profits. That deal would be FDI if traditional users got, say, $\$ 120$ for the land (more than it is worth to them plus some share of the profits) but a grab if they received only $\$ 50$. How could such a grab occur? When the selling country's ruler approves the deal over the objections of 'his' people. He benefits by keeping the extra money ( $\$ 150$ out of $\$ 200$, instead of $\$ 80$ ), but he may also please investors by lowering the price to $\$ 160$, for example, to make them simultaneously happier with higher profits and more inclined to ignore peasants robbed of their land.

The role of the ruler is key to understanding land grabs. As we will explain, land grabs are only possible when those in power approve unfair deals that existing users would not accept. That intervention happens in cases where rulers abuse power for their personal benefit, acting as corrupt and unaccountable 'kings' who care about their personal wealth - their rents from the land - more than social welfare or efficiency. Buyers play their own role - supporting land grabs in corrupt circumstances - but they do not have the ruler's market power.

Grabs are no innovation. They rely on a foreigner-ruler-peasant interaction that has existed for millennia and that dominated the colonial era. During the British Raj, for example, the East India Company (succeeded by the British Government) made deals in which local princes supplied land, labour and natural resources in exchange for payments that did not often benefit local peasants. Land grabs now - as those deals then - reduced princes' reliance on 'their' people at the same time as they used imported technologies to increase princes' wealth above levels possible from taxes based on local, traditional production. 
The increased intensity with which land and water resources are used within grabs or FDI is also not new. Intensification can increase wealth if it is done in a sustainable way, but overexploitation and destruction of fertility (via salination, topsoil degradation, groundwater depletion, and so on) leads to short-term poverty and long-term collapse (Fagan 2011). Such events are painful when local farmers destroy their own land; they are doubly painful when foreigners engaging in unsustainable grabs destroy land and water resources - leaving the ruins to locals without alternative ways to produce food.

We do not, thus, claim to have identified a new paradigm in resource exploitation or political economy. Land - and water - grabs are merely the latest way for those with power to advance their goals. What is new, perhaps, is that grabbers now come from countries that were exploited in the past. Those business and political elites are expanding their domestic power abroad via grabs.

However, is this narrative true? Or is it based on a few examples extrapolated into a trend by 'grab activists' with more ideology than hard data? In this chapter, we want to distinguish between bad grabs and good FDI so we can understand which deals are worthy of support or condemnation, separate good deals that maximise food production and minimise social instability from bad deals that deplete land and water resources, and clarify the relative negative impacts of poor management and disruptive changes in global temperature and precipitation patterns on local agricultural output (Fischer et al. 2005). These differences are not only useful to academics. They are important to politicians, insurance companies, agribusiness companies, and - not least - the Earth's 7 billion people

Our appraisal faces the same problems of every other appraisal in this book. We do not have complete information on deals identified as 'land grabs'. We do not know what contracts say. We do not know how contracts - if they exist - are being implemented or how production practices affect land, water, labour resources on and around land subject to 'grabs'.

Lacking these details, we try identify the modern forces behind grabs and predict where they may have the strongest impacts on local people and resources. To do this, we begin by examining the drivers of land grabs and their impact on water resources. We then use a stylised model of political-economy of development, governance, land grabs and imperialism to understand the relationship between rulers and peasants, and how a deal with outsiders may be a harmful grab instead of sustainable FDI. We then analyse deals that have alread $y$ been labelled as 'land grabs' in sub-Saharan Africa (SSA) to explore how corruption and accountability might help us separate grabs from FDI and assess where land grabs may damage water resources. From a social welfare perspective, our goal is simple: we want to reduce the number of unsustainable, unfair land grabs without preventing productive, sustainable FDI deals that improve global food supplies, support local communities and benefit investors.

\section{Background: demand, supply, land and water}

Population growth and economic development are increasing global demand on the extensive and intensive margins for food, biofuels and timber. Policies promoting biofuel production and carbon reduction further increase the demand for food crops or reduce land available for food production (Görgen et al. 2009; Anseeuw et al. 2012). Most deals also increase the demand for water. We will concentrate on food, biofuel and timber deals that account for nearly $90 \%$ of land deals in Africa and over $80 \%$ of deals world-wide (Anseeuw et al. 2012). ${ }^{3}$ Although most deals increase land- and water-use intensity, there are different ways to do so. FDI increases output using better technologies and techniques (hereafter 'technologies'); land grabs increase short-term output by sacrificing long-term land fertility and water resources. 
Note that we treat buying firms as 'countries' in this discussion. First, because some firms actually act on behalf of national governments. Second, because firms often share formal and informal institutional characteristics with their home countries. Third, because firms are often subjected to oversight by their home countries. Finally, because we have insufficient information on buying firms to assess their motivation or governance. On the sell side, we need only talk about national governments. First, there do not appear to be any private parties selling or leasing land to foreigners in our dataset of deals labelled as grabs. Second, even if there were, those deals would not happen without government approval. Third (again), because we only have data on national government corruption and accountability. Further, while land grabs may also be made by domestic investors, this chapter only focuses on foreign investments.

\section{The where, why and how of land grabs}

GRAIN's 2008 list of 'land grabs' included information on the parties to the deal (target country and grabber), origin of the grabber (private-sector/government), and announced crop. GRAIN divided grabbers into private investors seeking financial returns and governments seeking secure food

supplies, e.g. the People's Republic of China, Egypt, the Gulf States, India, Japan, the Republic of Korea (South Korea), Libya and Saudi Arabia. Friis and Reenberg (2010) used cross-checked 2008-10 data from the International Land Coalition (ILC) to assess 177 deals in 27 African countries. Ethiopia, Madagascar and Sudan have more than 20 deals each, but deals are heterogeneous in area and crops. GRAIN (2012a) updates their data to include over 400 grabs affecting 35 million hectares in 66 countries, with most activity in the 43 continental SSA countries. ${ }^{4}$ Two-thirds of the buyers are agribusinesses; one-third are financial investors and sovereign wealth funds.

Woertz et al. (2008) assess the potential for Gulf Cooperation Council countries to engage in land grabs in Africa and Central Asia (based on macro-economics and potential productivity), concluding that Mozambique, Sudan and South Africa are the most promising countries for investment. Deininger et al. (2011) use an econometric model based on announced land deals to investigate the factors associated with investor interest. Investors are more likely to make deals in countries with abundant non-forested areas and where rural people have weak land tenure rights. They also find that investment protection has only a weak impact on investors' decisions; protection is important in non-land FDI deals.

From a market perspective, grabs are likely to increase local and global food price volatility and perhaps increase price levels. On a local level, grabbed land produces crops for distant consumption, lowering local supplies and raising local prices. On a global level, grabbed land could increase total supplies by using better production technology - easing global scarcity - but the increase in total supply would be even greater if it was linked to profit-maximising FDI aimed at producing crops that fill supply-demand gaps instead of particular crops sold at subsidised prices to meet domestic demand.

\section{The demand side of land grabs}

Land grabs are made by two types of investors: food security seekers and financial investors (GRAIN 2008). Food security seekers want to increase domestic supplies and buffer local populations against global food price shocks, putting more trust in direct control over food production than in sourcing food from markets based on their willingness to pay. The cost of food acquired in these deals may exceed global market prices, but national food security is not about price as much as quantity (household food security is about price). The demand for food security is particularly strong in countries with strained land and water resources, e.g. China, India and many countries in the Middle East (Woodhouse and Ganho 2011). Commodity traders, 
on the other hand, want to profit from increasing demand for food, feed, fibre and biofuels (Anseeuw et al. 2012).

Investors with global reputations to protect are less likely to engage in unsustainable grabs instead of sustainable FDI; those concerned with short-term security or profits are more likely to make grab deals, a useful strategy when their rule or business model is vulnerable to price volatility. Their partners to grab deals face similar problems, such as the risk of losing power. Of the 41 continental SSA countries tracked by EIU (2010), 33 have 'high' or 'very high' political instability.

\section{The supply side of land grabs}

A naive observer may look at official statistics and assume that it is possible to put 'vacant' land and 'undiverted' water to use (Woodhouse and Ganho 2011), but facts on the ground sometimes contradict statistics. A land investment in the USA or France, for example, only occurs when a willing seller passes title to a buyer. The land could only be irrigated if water was available from existing allocations. Water allocations may not be perfect, but their flaws are well understood, and everyone is subject to the same institutional limitations on water use. Developing countries, on the contrary, are more likely to have weaker land titles, underdeveloped water allocation mechanism, and institutions that are too weak to protect rights and equity (North 2005). Land grabs occur when governments give foreign investors the right to use land that is not really vacant and water resources that are already used informally - bypassing local users who may not know 'their' resources have been sold or who lack the right to challenge a deal made under international law (Smaller and Mann 2009).

We hypothesise that deals are more likely to be grabs when rulers are less accountable to their citizens and/or abuse of power (corruption) is greater; they allow grabs when they prefer fast money (direct investment) from foreigners to slow money (taxes) from domestic 'owners' of land and water resources. FDI deals are more likely when accountability is greater and corruption less of a concern. While a buyer's attitude towards corruption and home-country accountability matters, it is the sell-side government that decides if a deal is going to be a grab or FDI.

Görgen et al. (2009) suggest that grabs can be identified by examining contractual wording, legal jurisdiction, rights of stakeholders, buyer and seller identity, and other structural characteristics of the deal, but the impact of a deal depends on implementation, who gets paid, whose water gets used, and so on. It is difficult to find answers to these questions (even for FDI), so we focus on the necessary conditions separating grabs from FDI. Are selling governments inclined to act in a transparent manner consistent with the best interests of their people? Are buyers accountable for their actions or motivated to avoid grabs? If not, can land and water resources in targeted countries absorb additional demand? The first 'no' indicates that a deal is likely to be a grab; the second 'no' indicates that the grab may have significant negative impacts on locals.

\section{The water dimension to land grabs}

Water access is key to deals in water-scarce areas outside SSA's humid equatorial zone. Anseeuw et al. (2012) find that land deals concentrate in areas with secure access to water, e.g. adjacent to the Nile and Niger rivers. They conclude (p. 37) that 'access to water is one of the key drivers of transnational land acquisitions', and increasing demand for food, biofuels and timber will increase the importance of access and pressure on water resources. Unfortunately, grabs that 'mine' water will have durable negative impacts. Land abandoned after a grab can often be used in some other way, but a grab that leaves no water behind may severely limit the use of the land in the long run.

Access can be sustainable or unsustainable, depending on the combination of rights to use groundor surface water and local water management practices. Rights are not created (or administered) 
equally. Skinner and Cotula (2011) describe how locals can lose customary rights that conflict with formal rights given to investors making grabs. Bues (2011) provides an example where an investor took over water previously used by small-scale irrigators in Ethiopia. These cases of conflict over rights to surface water clarify how the water impact of a grab can extend beyond the borders of land transferred to foreign investors, turning a zero-sum deal for land rights into a negative-sum deal in which water abstractions exceed physical and temporal flows (Woodhouse and Ganho 2011). In such conditions of mismanagement or lack of management over water resources (rights or no rights) grabs are likely to have negative impacts on local, downstream and future users of surface and groundwaters. Anseeuw et al. (2012), for example, report a failure to account for the cumulative impacts of irrigation projects in the Office du Niger area that resulted in negative impacts on downstream farmers, herders and fishermen.

Investors who blithely install high-capacity pumps to use 'their' groundwater can deplete neighbours' wells and reduce flows supporting springs and rivers. Those who attempt to 'secure' water supplies by building dams are likely to magnify damage to the environment and downstream users (Skinner and Cotula 2011). Investors making sustainable land deals will not only want to respect existing formal and informal rights to surface and groundwaters, but they will want managers to protect water resources over the long run. What is the long run? Many land deals are meant to last from 50 to 99 years. Some will be cut short by political instability, seller reneging or buyer abuse, but even contracts taken to term must leave water supplies in the same or better condition if they are to be 'sustainable'.

\section{Theory: kings as exploiters or protectors?}

Previous work on land grabs focused on the parties to the deals, the types of crops and the importance of land rights. We expand on this work by considering the relevance of governance (corruption and accountability) and water resources in land deals. Before we do that, we will motivate our discussion with a stylised model of why a king may wish to exploit - or protect 'his' people. This story - a simplified description of how 'big men' treat citizens as peasants and possessions - is familiar to students of European and colonial history, but it is not appropriate where democratic accountability puts leaders in the service of people or the king's role as big brother puts him in service to his tribe as an extended family. This story will make it easier to understand how a ruler determines whether a deal is a grab that harms his people or FDI that helps them.

\section{A king and his peasants}

Consider a political territory with king and peasants. The king has a monopoly on power; he acts as a stationary bandit who provides security from neighbouring kings (bandits) in exchange for a share of peasants' observed output (Olson 1993). These taxes are higher when peasants cannot leave the territory or organise resistance, but they are less than $100 \%$ of their production because the king wants them to produce in the future. Put differently, the king and peasants work within a sharecropping model in which the king allows the peasants to use land in exchange for a share of their observed crop that is paid in cash instead of in kind (Eswaran and Kotwal 1985). The king allows new technologies if greater production increases his income. Peasants will use these technologies if they are not made worse off.

We define an 'impatient' king as one who increases current production at the expense of future production, by mining natural resources faster than they are replenished or dumping waste into the environment instead of bearing the cost of processing it. A 'dynastic' king pursues sustainable 
practices to enrich his heirs. In all cases, the king's policies reflect input constraints among water, land and labour, and he will focus management on the binding resource, i.e. water in an arid region, land where population is high, or labour when land and water resources are abundant.

\section{Kings, imperialists, property rights and sustainability}

A dynastic king and dynastic peasants favour rules and practices that give weight to future production and thereby reduce current waste of resources. Both sides, for example, prefer to use labour today to improve soil fertility for greater production tomorrow. An impatient king or impatient peasants take short cuts today that reduce production tomorrow.

An impatient king has no reason to strengthen others' property rights in resources; he will exploit forests, land and water. Impatient peasants will exploit any open access resource they can. As examples of these phenomena, consider a centralised, agrarian society (e.g. the Maya), a resource-exploiting society (e.g. Saudi Arabia or the USSR).

A dynastic king with impatient peasants has to cope with their attempts to mine resources. $\mathrm{He}$ can try to induce patience by giving them secure title to land and water. This property rights thesis recently associated with Peruvian economist Hernando de Soto - holds that peasants with secure rights will invest and conserve today so they can benefit tomorrow, allowing the king to grow wealthier through taxes than he would have with punitive seizures of land or crops.

Depending on the king's goal, new technologies make it easier to exploit or conserve resources by altering the relative importance of land, water and labour. Pumps that replace manual water hauling make it possible to farm more land with less labour. Such a technology can turn water into the limiting resource as it reduces the relative value of land and labour.

A king replaced by foreign imperialists will result - all things equal - in less sustainable practices devoted to exporting wealth to home territories. Thus, we can see how the British in India may allow famine as they seek mercantile revenues or the Spanish may destroy indigenous cultures to extract resources from the New World.

Imperialists also exploit more because they can implement technologies that loosen constraints on resource consumption. British trains and timetables increased Indian land and labour productivity, but British irrigation works vastly increased water demand. Those projects turned water into the limiting factor in agricultural production and increased the rate of water consumption often above sustainable levels.

As a counterpoint to imperialism, consider an indigenous growth model in which the king protects property rights, listens to his people, provides reliable administration and uses taxes to provide public goods. Peasants under these conditions have an incentive to plan and act for the long term, with the assurance that most of their effort will increase their own wealth.

\section{Land grabs as neo-imperialism}

Land grabs result from co-operation between impatient kings who give investors cheap access to land and protection in exchange for fast money and foreigners whose use of local resources and imported technologies to produce goods for export gives deals an imperialistic flavour. Land grabs displace local development by assigning land to foreign investors instead of strengthening peasants' informal or communal property rights (North 2005). They reduce local innovation in favour of imported technologies, direct scarce resources to cash crops, and promote big planned deals over numerous decentralised small innovations (Easterly 2006).

Foreign direct investors are willing to pay more in the short run to get a better long-run return. They are therefore happy to deal with benign kings but not corrupt kings who are likely 
to seize their investments before they can earn their 'fair' returns based on a long-term yield of lower but sustainable outputs.

Water is necessary but not sufficient for land deals in the sense that most intensive cultivation requires adequate water supplies, but adequate water is not enough to make a deal happen. Both FDI and grabs will use water, but that use - by definition - will be more and less sustainable, respectively. FDI deals need secure water over many years, which means that consumption cannot deplete water for neighbours or the environment. Land grabs are likely to have even more exploitation in their water dimension than their land dimension. First, because deals are likely to create novel and formal rights over water that was previously allocated through informal and communal mechanisms. Second, because water use intensity is likely to rise as intensive agriculture replaces indigenous technologies suited to local conditions, leaving less water for locals and the environment. Third, because industrial agriculture is more likely to produce contaminated runoff that affects downstream neighbours.

Although we consider kings or rulers to be exogenously corrupt - or not - based on their power over their people, we must also note that foreign investors are less likely to participate in grabs if they are subject to voice and accountability in their home countries, e.g. criticism for investing where human rights abuses take place. As an example, consider the different perceptions of deals made in Sudan. Western firms and governments faced criticism for co-operating with the Sudanese Government while the Darfur genocide was receiving heavy news coverage, but Chinese and Saudi investors were happy to deal with the government.

From this example and our characterisation of the relationship between a king and foreign investor, we can put deals into a two-by-two matrix, with a pro- or anti-grab king on the top and a pro- or anti-grab investor on the side. Their pro- or anti-grab position is determined by their attitudes towards corruption and accountability towards citizens. From these characteristics, we can see two stable equilibria: FDI (anti-anti) or land grab (pro-pro). The off-diagonal squares represent crossed-wire scenarios in which a pro-grab (corrupt and unaccountable) king has a hard time convincing an anti-grab investor to exploit his people, or where an anti-grab king thwarts a pro-grab investor. These mismatches are not stable. The king and investors will quickly discover that they need new (grab or FDI) partners.

\section{Analysis: corruption, land grabs and sustainability}

\section{A thorough analysis is impeded by missing data}

An investigation of the linkages between governance, property rights, peasant exploitation and sustainable use of land and water would require detailed information on the identity of the investor (publicly traded company or private partnership) and contracting party (a local community or a bureaucrat in the capital); details on formal or informal rights to the land; current and future water consumption in the area; details on soils, technology and labour; a description of payment flows for land, water, inputs and labour; and a reconciliation of the written contract with its actual economic, social and environmental impacts.

Although it may be easier to acquire these data for FDI in places like Australia, they are difficult to find under normal conditions in SSA (due to lack of capacity or bureaucratic turf wars) and extremely difficult to uncover when deals are obscured in the interests of national security, corrupt dealings or commercial confidentiality - interests that outsiders cannot often separate (World Bank 2012). Secrecy is likely to be founded on a desire to avoid 'international scrutiny and accountability in case of political conflicts' or make corrupt deals that extract 
benefits for parties to the deal while dumping costs on average citizens and the environment (Woertz et al. 2008: 21; Smaller and Mann 2009).

It is, in fact, difficult to find complete, coherent and transparent information on land deals, whether they be grabs or FDI. Such a gap makes it hard to separate FDI from grabs, understand the magnitude of individual deals, or even see the 'official version' of deals. What is ironic is that the data we do have for 'land grabs' may oversample legitimate FDI deals that nobody wants to hide from public scrutiny.

What is strange is that most of what we know about land deals in Africa comes from researchers or activists more interested in grabs than FDI. GRAIN - 'an non-governmental organization (NGO) that works to support small farmers and social movements in their struggles for community-controlled and biodiversity-based food systems' - released its first list of land grab deals in 2008. This list was updated and cross-checked to 173 SSA grabs by Friis and Reenberg, who caution that their data - like others relying on sources such as 'farmlandgrab. org' - may suffer from 'significant differences in credibility' (Friis and Reenberg 2010: 9).

The most recent data come from GRAIN (2012b), a dataset of 416 'land grab' deals from around the world that includes variables for targeted country, area, projected investment, country of the investor, investor type (e.g. agribusiness), crop type and deal status. We use 203 SSA deals, of which 201 deals are either 'done' or 'in process' (the other two deals are 'suspended'); see Table 3.3.1. This dataset, unfortunately, is not complete. It covers only uncancelled transactions for the production of food crops on large plots of land that foreign investors initiated after 2006. Even if GRAIN were successful in listing all deals with these characteristics - which is unlikely - they did not cover deals involving non-food cash crops such as jatropha or cotton (GRAIN 2012a).

These uncertainties make it difficult to distinguish between 'real' FDI deals that create wealth and improve local economic conditions in a sustainable way and 'grabs' that expropriate local land and water resources for the benefit of corrupt rulers and callous investors. With enough data, we could make a political-agro-economic evaluation of each project over time, to separate grabs from FDI, but we don't have those data. What we have is information on a few variables that we would expect - from the theory outlined above - to be correlated with land grabs and over-exploitation of resources. The next sections describe those data and how we try to use them to distinguish between grabs and FDI. ${ }^{5}$

\section{Land grabs, corruption, voice and accountability}

The World Bank provides data on control of corruption and voice and accountability for 213 countries (Kaufmann et al. 2010). Control of corruption (CC) measures the extent to which

Table 3.3.1 Data coverage on land deals in SSA

Criteria

Number of entries

Total number of deals inside SSA country

201

Information on size of land deal (ha)

201

Information on projected investment (\$)

51

Information on base country of investing entity

201

Information on investing entity

201

Of these, investors identified as 'government'

23

Information on crop

183

Source: GRAIN (2012b). 
public power is exercised for private gain, including both petty and grand forms of corruption, as well as 'capture' of the state by elites and private interests. The indicator on voice and accountability (VA) measures the extent to which a country's citizens are able to participate in selecting their government, as well as freedom of expression, freedom of association, and a free media. These good governance indicators have values between -2.5 (worst, i.e. most corrupt or least accountable) and +2.5 (best, i.e. least corrupt or most accountable), with 0 as the median value.

In the following analysis, we used 95 of the 201 SSA deals from GRAIN (2012b) that involved the same country pairs (buyers identified from one country and sellers) in two or more deals. This smaller dataset helps us concentrate on the 17 SSA countries that are systematically engaged in 'grabs'. We will occasionally compare these countries to the other 26 continental SSA countries with less grab activity. Table 3.3.2 divides these 95 deals into four groups according to their $\mathrm{CC}$ values: low CC buyer-low CC seller, low CC buyer-high $\mathrm{CC}$ seller, and so on.

Based on the theory of impatient kings outlined above, we expect deals in low-low pairs to be grabs in which buyers and sellers co-operate to extract rents from land and water resources.

Table 3.3.2 Analysis of SSA deals: control of corruption

\begin{tabular}{|c|c|c|c|}
\hline & & \multicolumn{2}{|l|}{ Sellers } \\
\hline & & Low CC $(-2.5$ to 0$)$ & High CC (0 to 2.5) \\
\hline Buyers & $\begin{array}{l}\text { Low CC } \\
(-2.5 \text { to } 0)\end{array}$ & $\begin{array}{l}\text { Brazil-Mozambique (2) } \\
\text { China - Benin (2) } \\
\text { China - Senegal (2) } \\
\text { China - Sierra Leone (2) } \\
\text { China - Uganda (2) } \\
\text { Egypt - Sudan (5) } \\
\text { India - Ethiopia (13) } \\
\text { India - Madagascar (2) } \\
\text { India - Tanzania (3) } \\
\text { Italy - Rep Congo (Brazzaville) (2) } \\
\text { Italy - Mozambique (2) } \\
\text { Libya - Mali (2) } \\
\text { VietNam - Nigeria (2) } \\
\text { Portugal - Angola (3) } \\
\text { Portugal - Mozambique (4) } \\
\text { Saudi Arabia - Mauritania (2) } \\
\text { Saudi Arabia - Sudan (4) } \\
\text { Singapore - Tanzania (2) } \\
\text { South Africa - Mozambique (4) } \\
\text { UAE - Sudan (6) } \\
\text { UK - Mali (3) } \\
\text { UK - Mozambique (5) } \\
\text { UK - Sierra Leone (5) } \\
\text { UK - Zambia (2) } \\
\text { USA - Mali (2) } \\
\text { USA - Sudan (2) } \\
\text { USA - Tanzania (4) }\end{array}$ & $\begin{array}{l}\text { Germany - Ghana (2) } \\
\text { UK - Ghana (2) } \\
\text { UK - Namibia (2) }\end{array}$ \\
\hline
\end{tabular}

Source: Deals from GRAIN (2012b) and CC from Kaufmann et al. (2010).

Note: Of the 95 land grab deals, 89 occur in countries with low CC scores, i.e. more corruption. The deal count is shown in () for each buyer-seller country pair. 
In fact, $94 \%$ of the 95 deals are in low CC countries, with 41 in low-low country pairs and 48 between high CC buyers and low CC sellers. High CC buyers may be participating because they are less corrupt at home than they are abroad (the deals are grabs) or their investments are actually FDI. Given the difficulty of objectively judging whether deals can be categorised as FDI or grabs from our incomplete information, it could be that some 'grabs' are actually FDI.

These generalisations do not prevent a number of reasonable explanations for deal-pairs. Egypt might be investing in Sudan to improve relations or move 'use' upstream. Some buyers may also be investing because of 'gravity' (proximity), religious ties and/or long-term relationships. The USA and China - lacking geographic or historical links that might associate them with certain SSA countries - might pay more attention to corruption, but they both invest in countries with an average $\mathrm{CC}$ of -0.76 .

Indeed, low and high $\mathrm{CC}$ buyers invest in countries with median $\mathrm{CC}$ values of -0.73 and -0.67 , respectively. That said, separating high CC buyers into Arab and non-Arab countries reveals that the former invest in countries that are more corrupt, i.e. median CC of -1.21 vs -0.42 in countries targeted by European buyers.

We can add more depth to the discussion by looking at VA, to test the idea that land grabs are more likely to occur in countries where citizens cannot hold their governments accountable - countries with negative VA values. Table 3.3.3 segregates our 95 deals by VA values.

Some $82 \%$ of the deals in Table 3.3 .3 occur in low-VA countries; 27 of them - the ones in low-low country pairs - are more likely to be land grabs than FDI. The 51 deals between high VA buyers and low VA sellers, like the high-low CC deals in Table 3.3.2, may be either quiet grabs or FDI misclassified as grabs.

As with CC, VA grouping shows that high and low VA buyers make deals with different countries within the low VA set of sellers. Low VA buyers invest in countries with median VA values of -1.66 ; median VA values are -0.27 in selling countries with high VA buyers. The United Kingdom (VA: 1.32), for example, invests mostly in relatively high VA countries (Mozambique: -0.06; Sierra Leone: -0.27 ; and Zambia: -0.3), but India (VA: 0.49) made 72\% of its deals in Ethiopia (VA: -1.30). While some high VA countries also invest in countries with lower VA values, e.g. the USA made $33 \%$ of its deals in Sudan (VA: -1.66 ), the majority of the investments are made in high VA countries.

High VA buyers may be investing in countries with higher VA because they face scrutiny at home. Those deals are also less likely to be grabs. That said, we should also note that only 10 of 47 SSA countries have positive VAs. While three high-VA countries (Ghana, Namibia, Mali) are included in the GRAIN (2012b) database, other countries with plenty of FDI and positive VA values (Botswana, South Africa and others) are not. Although some missing deals may be sustainable FDI, others could be land grabs (false negatives). The lack of a complete dataset on all deals makes it hard to differentiate between grabs and FDI, so we must concentrate on false positives, i.e. 'land grabs' in GRAIN data that are actually FDI.

A comparison of CC and VA values in our 17 SSA grab countries to values in the other 26 continental SSA countries does, in fact, raise serious questions on whether or not GRAIN's deals are exploitative grabs. From our theory, we expect corrupt (impatient) rulers to engage in grabs and benevolent (dynastic) rulers to sign FDI deals, but the average CC value in the 17 'grab' countries $(-0.66)$ is quite close to the average $(-0.69)$ in the other 26 countries. The difference in VA values ( -0.46 and -0.91 , respectively) is greater but in the wrong direction. CC and VA values should be lower, not higher, in countries actively engaged in deals if those deals are grabs, but not if those deals are FDI. These results (which are not contradicted below) cause us to question the 'grab' label on these deals. 
Table 3.3.3 Analysis of SSA deals: voice and accountability

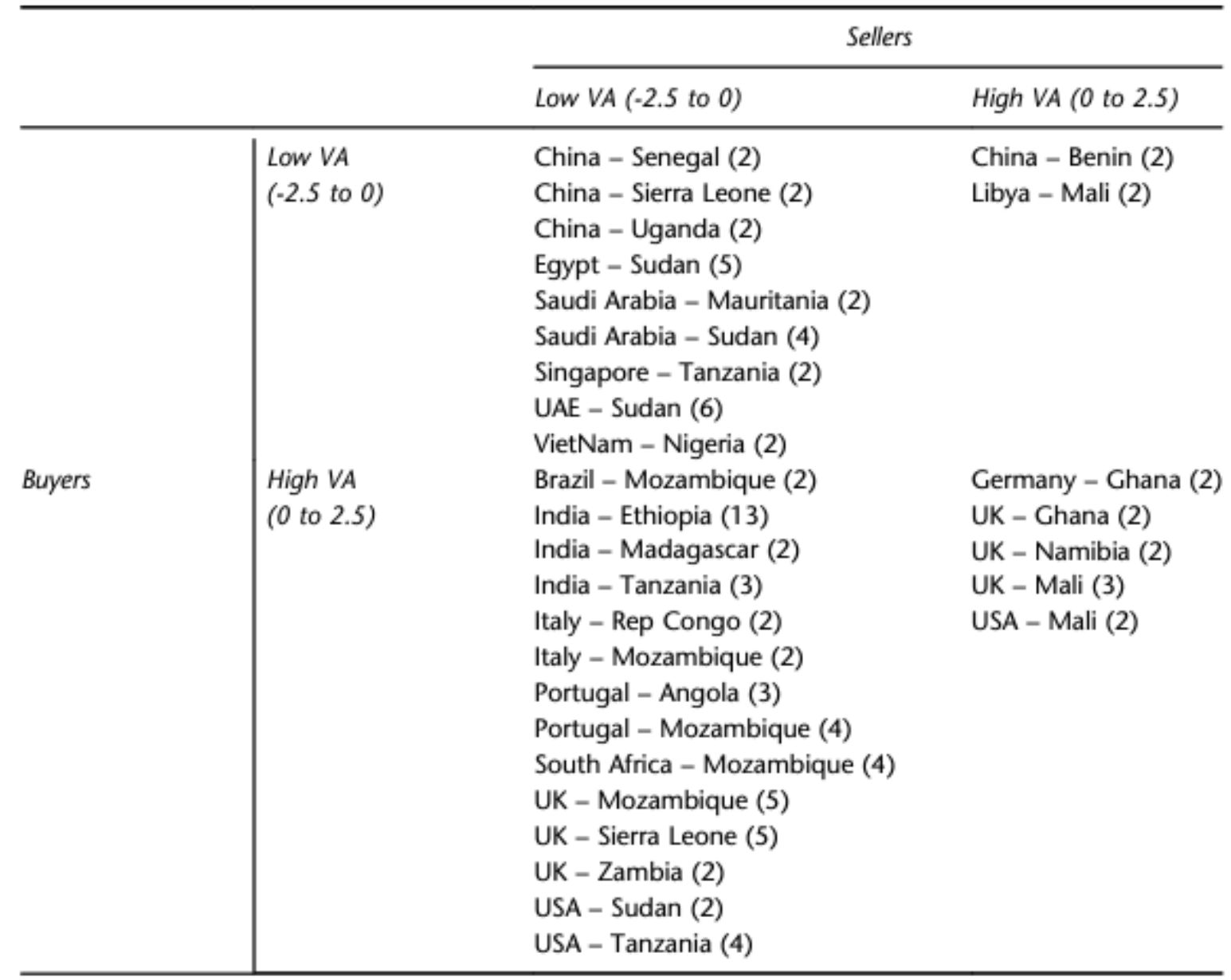

Source: Deals from GRAIN (2012b) and CC from Kaufmann et al. (2010).

Note: Of the 95 land grab deals, 80 occur in countries with low VA values. The deal count is shown in () for each buyerseller country pair.

Some countries move between quadrants in Tables 3.3.2 and 3.3.3, so we created a single, but crude, good governance (GG) indicator for all countries in the 95 deals that is based on the average of $\mathrm{CC}$ and VA values. These results, shown in Table 3.3.4, make it easier to discuss 'governance' below.

Some $94 \%$ of the deals took place with low GG sellers (more corruption and lower accountability). Twenty-three deals involve low-low country pairs, while high GG buyers made 66 deals in low GG countries. Low GG buyers invested in countries with a median GG value of -0.74 ; high GG buyers invested in countries with a median GG of -0.46 . Note that this difference would be even greater if we excluded developing countries with barely positive GG values, i.e. Brazil $(G G=0.19)$, India $(G G=0.03)$, South Africa $(G G=0.32)$ and $U A E(G G=$ 0.09 ), from the high GG buy side, since the remaining buyers in the 'high-low' category invested in countries with a median value of -0.27 . Put differently, our data indicate that GG values for buyers are higher than GG values for their sellers, but GG values of buyer-seller pairs tend to rise together (correlation 0.33).

\section{Land grabs and pressure on water resources}

Although all investors in agricultural land consider water availability when making deals, we assume that 'grabbers' are interested in maximising current output at the expense of long-term 
Table 3.3.4 Analysis of SSA deals: good governance

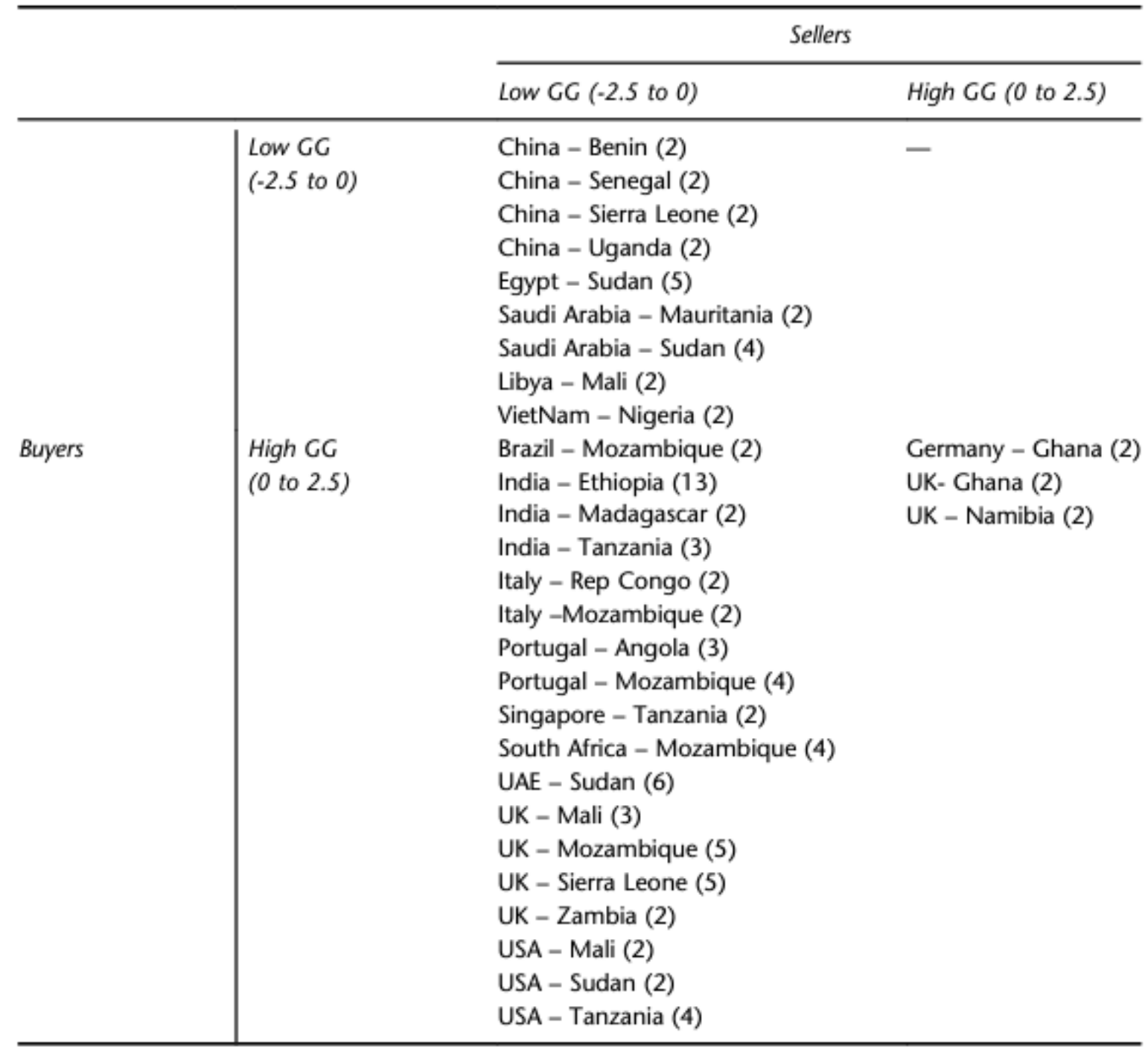

Source: Deals from GRAIN (2012b); CC and VA from Kaufmann et al. (2010).

Note: Of the 95 land grab deals, 89 occur in countries with low GG values. The deal count is shown in () for each buyer-seller country pair.

sustainability. We can thus predict that grabbers are more likely than FDI-investors to deplete soils - overusing fertiliser for short-term boosts rather than engaging in labour-intensive soil management - and more likely to overuse water resources than save water for the next season or invest in water conservation technology. Even ignoring the short-term view of grabbers, we assume that FDI is also going to increase pressure on water and land resources because they are likely to replace traditional farming technologies that may rely on rainfall, natural soil fertility and basic implements with industrialised technologies that increase output by intensifying water consumption, planting density, mechanisation, and so on. The difference between the two is that grabbers are more likely to abuse their preferential access to water than FDI investors, since they care more about short-term production. FDI investors have a greater contractual or informal incentive to manage water resources sustainably because they need to have good relations with neighbours in the short run and protect water resources and the environment in the long run.

We explore these propositions by examining data for rainfall variability, total actual renewable water resources, current use of water resources and rural land tenure recognition. We use this 
last variable as a proxy for water rights, under the assumption that weak land tenure is correlated with weak water rights and/or controls on water use. We will discuss each variable before introducing a weighted index value for 'water vulnerability' for each selling country based on these variables, each of which has been normalised to a value of 0 to 1 , with 1 corresponding to higher pressure on water resources. Our theory is that grabs will occur in water-vulnerable countries because investors are not worried about long-term water availability; FDI, in contrast, will be targeted at less vulnerable countries because water resources are necessary to long-run, sustainable deals.

For rainfall variability, we use standard deviation of rainfall for the 40+ years between 1961 and 2002 given in FAO CLIMPAG data. Higher variability implies greater pressure on surface and groundwater resources. For total actual renewable water resources (TARWR, in $\mathrm{m}^{3} / \mathrm{ha} /$ year), we use FAO Aquastat data from 2009. ${ }^{6}$ We assume that areas with lower renewable water resources per arable hectare will have - all things equal - more competition for water, a higher likelihood of pressure on water resources, and negative environmental, economic and social implications. The percentage of TARWR withdrawn, also from FAO Aquastat, indicates existing pressures on TARWR from all uses. For rural land tenure recognition, we use data from the Institutional Profiles Database (2009). These data describe a country's population with formally recognised land rights in rural areas on a $1-4$ scale (the highest value in SSA is 3 , so normalised values rise in steps of 0.33 ).

We combined each of these variables using equal weights to create a basic index of water vulnerability, as shown in Table 3.3.5. Note that this index provides only a rough guide to vulnerability, since local conditions determine water resource availability.

Table 3.3 .5 Index of water vulnerability

\begin{tabular}{|c|c|c|c|c|c|}
\hline & $\begin{array}{l}1961-2002 \\
\text { rainfall variability, } \\
\text { from } 0 \text { (low) to } \\
1 \text { (high) }\end{array}$ & $\begin{array}{l}\text { TARWR per } \\
\text { arable ha, } \\
\text { from } 0 \text { (high) } \\
\text { to } 1 \text { (low) }\end{array}$ & $\begin{array}{l}\text { Percentage of } \\
\text { TARWR } \\
\text { withdrawn, } \\
\text { from } 0 \text { (low) } \\
\text { to 1(high) }\end{array}$ & $\begin{array}{l}\text { Rural land } \\
\text { tenure } \\
\text { recognition, } \\
\text { from } 0 \text { (more } \\
\text { local rights) } \\
\text { to } 1 \text { (fewer) }\end{array}$ & $\begin{array}{l}\text { Weighted } \\
\text { average of } \\
3 \text { or } 4 \text { variables } \\
\text { (1 is worst) }\end{array}$ \\
\hline Sudan $(-1.45)$ & 0.23 & 1.00 & 1.00 & 0.33 & 0.64 \\
\hline Senegal $(-0.42)$ & 0.44 & 0.99 & 0.10 & 0.67 & 0.55 \\
\hline Sierra Leone $(-0.60)$ & 0.64 & 0.91 & 0.01 & - & 0.52 \\
\hline Mali $(-0.28)$ & 0.27 & 0.99 & 0.11 & 0.67 & 0.51 \\
\hline Nigeria $(-0.92)$ & 0.33 & 0.99 & 0.06 & 0.67 & 0.51 \\
\hline Uganda $(-0.68)$ & 0.35 & 0.99 & 0.01 & 0.67 & 0.51 \\
\hline Madagascar $(-0.54)$ & 0.62 & 0.93 & 0.08 & 0.33 & 0.49 \\
\hline Tanzania $(-0.27)$ & 0.51 & 0.99 & 0.09 & 0.67 & 0.48 \\
\hline Angola (-1.29) & 0.23 & 0.98 & 0.01 & 0.67 & 0.47 \\
\hline Benin $(-0.18)$ & 0.43 & 0.99 & 0.01 & 0.33 & 0.44 \\
\hline $\begin{array}{l}\text { Mozambique } \\
(-0.24)\end{array}$ & 0.44 & 0.97 & 0.01 & 0.33 & 0.44 \\
\hline Zambia (-0.42) & 0.43 & 0.98 & 0.03 & 0.33 & 0.44 \\
\hline Ethiopia (-1.00) & 0.33 & 0.99 & 0.08 & 0.33 & 0.43 \\
\hline Namibia $(0.26)$ & 0.35 & 0.99 & 0.03 & 0.33 & 0.42 \\
\hline Ghana $(0.28)$ & 0.57 & 0.99 & 0.03 & 0.00 & 0.40 \\
\hline Mauritania $(-0.74)$ & 0.18 & 0.98 & 0.24 & 0.00 & 0.35 \\
\hline Rep Congo $(-1.14)$ & 0.42 & 0.00 & 0.00 & 0.67 & 0.27 \\
\hline
\end{tabular}

Source: Author calculations.

Note: Indexed 'water vulnerability' values ( 0 good, 1 bad) for selling countries, sorted from high to low; GG values in 0 . 
Table 3.3.5 indicates that Sudan has the highest water vulnerability. Land grabs, therefore, are more likely to exert pressure on Sudan's people and environment. Add Sudan's low score on good governance - or high score for corruption - and we can see how Sudan's rulers may be signing deals that not only short-change their people in the near term but also put their long-term survival at risk. At the opposite extreme are Namibia and Ghana, with a combination of higher GG and lower vulnerability to water over-exploitation. 'Grabs' in Ghana and Namibia are more likely to be FDI that benefits local people in the long run. Countries with low water vulnerability values, such as Mauritania and the Republic of Congo, may suffer from land grabs due to corruption, but those grabs will only cause long-term environmental damage if they achieve significant scale.

Note that all of these statements, like all of our data, are generalisations of potential trends on a national scale; they may not reflect actual water conditions at deal locations. It is obviously possible to have sustainable FDI in parts of Sudan where rulers care about the welfare of local people, as well as unsustainable grabs in parts of Namibia where rulers are more interested in their personal wealth than the welfare of their people (see Workman 2009). Even more important is to recognise that these deals may be occurring in the least vulnerable countries within SSA. The average water vulnerability index value is 0.46 for our 17 countries with the most 'grab' activity but 0.50 for the other 26 SSA countries with fewer (or zero) deals, indicating that deals are occurring within a subset of countries that are slightly less vulnerable to water scarcity.

\section{A tempest in a teapot?}

In this chapter, we have explored the connection between land grabs, governance and water resources. Building on a theory of 'kings and peasants' that clarifies the dominant role of rulers with power over their people, this chapter describes how 'kings' - the rulers of countries targeted for investment - determine whether deals are land grabs that exploit local people and resources for short-term gain or FDI that generates sustainable wealth. We claim that land grabs are more likely when both parties to the deal are corrupt and citizens with a weak voice cannot hold rulers accountable for their actions.

To apply the theory, we calculated a good governance index combining measures of corruption, citizen voice and ruler accountability for the countries most active in 'land grabs' in sub-Saharan Africa. We found that $94 \%$ of the 95 deals involved selling countries with low scores on good governance. Buyers, however, fell into two groups. Buyers with poor governance (e.g. Saudi Arabia) made deals with sellers that had lower governance scores while buyers with higher governance scores (e.g. the United Kingdom) dealt with sellers that had relatively higher governance scores. Although high governance buyers may be participating in grabs, they may also be engaged in sustainable FDI. Countries with higher governance scores (such as the UK) may avoid land grabs, but they cannot prevent countries with lower governance scores acting as buyers in land grabs. What they can do, perhaps, is encourage selling countries to increase the transparency with which they make deals, to make it easier for outsiders to see whether these deals are detrimental grabs or beneficial FDI.

In a second step, this chapter analyses the water vulnerability of targeted countries based on rainfall variability, total actual renewable water resources, withdrawn water resources and rural land tenure recognition. The assessment indicates that some targeted countries are indeed vulnerable to unsustainable over-exploitation of water resources. Sudan stands out as the most vulnerable country among those we examined. Although it is difficult to generalise from national statistics to the particulars of a local deal, Sudan's combination of high corruption and low accountability, high water exploitation and weak land tenure means that its people may suffer from an increase in agricultural investment that has been both predicted and encouraged for decades. 
These results - derived from the most recent, most complete set of 'grab' data - lead us to question whether or not some of these deals are FDI instead of grabs. While it is clear that some grabs have occurred in SSA - some deals have attracted a lot of attention and analysis - it is not so clear that we know that much about all the other deals that are superficially similar but may be functionally different. Stepping back from GRAIN's data, we have even greater concerns. If land grabs are supposed to involve unprincipled and unsustainable exploitation of local communities and natural resources, then why is it that the 17 SSA countries most active in land grabs have similar or better rankings on scales of governance and water resources when compared to 26 other SSA countries that are not so active in grabs? Such a pattern - acknowledging the fact that no deals will occur in countries too corrupt to enforce any laws - is consistent with investors making sustainable FDI deals, not grabs.

In 20 years, we will know whether these deals were grabs or FDI. We will know who got rich, who got fed, who is still in business and who is considered a leader - or a traitor - to his people. However, 20 years is a long time to wait. Further research can help local and international observers understand whether these deals are really grabs or just misclassified FDI. This research should concentrate on analysing case studies, evaluating local water conditions and water vulnerability, and tracing the financial, social and ecological impacts of deals in local communities.

\section{Notes}

1 We thank two anonymous referees, Suzanne K. Larsen, Scott McKenzie, Anita Milman and Hans-Peter Weikard for their helpful comments. All content - and errors - are the responsibility of the authors.

2 The Tirana Declaration of 26 May 2011 defines 'land grabs' using subjective criteria.

3 These statistics refer to 'cross-referenced large-scale land acquisitions' - a subset of total land acquisitions that is difficult to characterize owing to missing information. Cross-referenced deals in Africa cover 34 million hectares; 'reported' large-scale deals in Africa total 134 million hectares - an area roughly double the size of France (Anseeuw et al. 2012).

4 Africa has 54 countries. We exclude five North African and five small island countries from our discussion. We treat Sudan and South Sudan as one country because their data are usually merged.

5 All data can be downloaded from http://kysq.org/pubs/grabs.xls.

6 Total Actual Renewable Water Resources: the sum of internal renewable water resources and external actual renewable water resources, which corresponds to the maximum amount of water theoretically available. We lack, unfortunately, data on groundwater stocks and flows. Such data would be very important for evaluating sustainability, since it is impossible to use more than the annual flow of a river but easier to consume decades or centuries of aquifer recharge in a single year.

\section{References}

Anseeuw, W., Alden Wily, L., Cotula, L. and Taylor, M. (2012) Land Rights and the Rush for Land: Findings of the Global Commercial Pressures on Land Research Project, Rome: ILC.

Bues, A. (2011) 'Agricultural foreign direct investment and water rights: an institutional analysis from Ethiopia', paper presented at the International Conference on Global Land Grabbing, April, University of Sussex.

Deininger, K., Byerlee, D., Lindsay, J., Norton, A., Selod, H. and Stickler, M. (2011) Rising Global Interest in Famland - Can It Yield Sustainable and Equitable Benefits? Washington, DC: World Bank.

Easterly, W. (2006) The White Man's Burden: Why the West's Efforts to Aid the Rest Have Done So Much Ill and So Little Good, New York: Penguin.

EIU (2010) Political Instability Index for 2009//10, Economist Intelligence Unit. Online. Available at: http://viewswire.eiu.com/site_info.asp?info_name=social_unrest_table (accessed 29 March 2012).

Eswaran, M. and Kotwal, A. (1985) 'A theory of two-tier labor markets in agrarian economies', American Economic Review 75(1): 162-77.

Fagan, Brian (2011) Elixir: A History of Water and Humankind, New York: Bloomsbury. 


\section{David Zetland and Jennifer Möller-Gulland}

FAO (2012) AQUASTAT Online Database, Rome: Food and Agriculture Organization of the United Nations. Available at: www.fáo.org $/ \mathrm{nr} /$ water/aquastat/data/query/index.html?lang=en (accessed 5 February 2012).

FAO CLIMPAG (2003) The National Rainfall Index (NRI) in the 1961-2002 Period. Online. Available at: www.fao.org $/ \mathrm{nr} / \mathrm{climpag} / \mathrm{nri} /$ nrilist_en.asp (accessed 10 February 2012).

Fischer, G., Shah, M., Tubiello, F. N. and van Velhuizen, H. (2005) 'Socio-economic and climate change impacts on agriculture: an integrated assessment, 1990-2080', Philosophical Transactions of the Royal Society B 360(1463): 2067-83.

Friis, C. and Reenberg, A. (2010) Land Grab in Africa: Emerging Land System Drivers in a Teleconnected World, GLP Report No. 1. Copenhagen: GLP-IPO.

Görgen, M., Rudloff, B., Simons, J., Üllenberg, A, Väth, S. and Wimmer, L. (2009) Foreign Direct Investment (FDI) in Land in Developing Countries, Eschborn: GTZ.

GRAIN (2008) SEIZED! The 2008 Land Grab for Food and Financial Security, Barcelona: GRAIN.

- (2012a) 'GRAIN releases data set with over 400 global land grabs', press release, 23 February. Online. Available at: www.grain.org/article/entries/4479-grain-releases-data-set-with-over-400-global-landgrabs (accessed 5 March 2012).

- (2012b) 'GRAIN land grab deals Jan. 2013. Database'. Online. Available at: www.grain.org/attachments/2453/download (accessed 5 March 2012).

Institutional Profiles Database (2009) IPD 2009. Online. Available at: www.cepii.fr/anglaisgraph/bdd/ institutions.htm (accessed 10 February 2012).

Kaufmann, D., Kraay, A. and Mastruzzi, M. (2010) Worldwide Govemance Indicators: A Summary of Methodology, Data and Analytical Issues, World Bank Policy Research Working Paper No. 5430, Washington, DC: World Bank.

North, D. C. (2005) Understanding the Process of Economic Change, Princeton: Princeton University Press.

Olson, M. (1993) 'Dictatorship, democracy and development', American Political Saience Review 87(3): 567-76.

Skinner, J. and Cotula, L. (2011) Are Land Deals Driving 'Water Grabs'? London: IIED.

Smaller, C. and Mann, H. (2009) A Thirst for Distant Lands: Foreign Investment in Agricultural Land and Water, Winnipeg, Canada: International Institute for Sustainable Development.

Woertz, E., Pradhan, S., Biberovic, N. and Jingzhong, C. (2008) Potential for GCC Agro-Investments in Africa and Central Asia, GRC Report, Dubai: Gulf Research Centre.

Woodhouse, P. and Ganho, A. S. (2011) 'Is water the hidden agenda of agricultural land acquisition in sub-Saharan Africa?' paper presented at the International Conference on Global Land Grabbing, April, University of Sussex.

Workman, James G. (2009) Heart of Dryness: How the Last Bushmen Can Help Us Endure the Coming Age of Permanent Drought, New York: Walker.

World Bank (2012) Doing Business 2012: Doing Business in a More Transparent World, Washington, DC: World Bank. 
Why does this PDF have a "funny" format? Because Routledge failed to deliver me the PDF of the chapter that I requested and Cathy of Routledge agreed to provide. (In the email below she says "I'll just need to run it by the appropriate people," but she never came back to me with objections in the seven months between that email and when the book came out.)

Note: I split EUR 120 with my co-author on this chapter - an amount that was double Routledge's payment because the editors donated their fees to chapter authors.

From: Hartley, Cathy [Cathy.Hartley@informa.com]

Date: Fri, Jan 13, 2012 at 12:19 PM

Subject: RE: Handbook of Land and Water Grabs in Africa - Routledge Contract

To: "Zetland, David" [david.zetland@wur.nl]

\section{Hi David}

Many thanks for the contract. Remind me once the book has been published, and I'll get the production people to send you a PDF copy of your chapter. I'll just need to run it by the appropriate people, but I think it should be OK to post a Routledge watermarked version with reference to the book.

Best wishes

Cathy

From: David Zetland [david.zetland@wur.nl]

Sent: 13 January 2012 10:58

To: Hartley, Cathy

Cc: Jennifer Moeller-Gulland

Subject: Re: Handbook of Land and Water Grabs in Africa - Routledge Contract

Hi Cathy,

Yes, I would just post it on my website - here: http://www.kysq.org/pubs.htm

I've attached a signed contract. The only change is in section 4. I am taking payment, since Jennifer's work has too many rules on that matter. If it's ok, then she will sign a version that omits payment.

Best

David

On Fri, Jan 13, 2012 at 10:17 AM, Hartley, Cathy [Cathy.Hartley@informa.com] wrote:

Dear David

Thanks for this. Please let me know what you mean by a PDF for distribution who would receive it, and how many copies would be distributed? We can forward you a PDF of your chapter, but this would normally be for personal use.

Best wishes

Cathy 